\title{
PERANCANGAN DAN PEMBUATAN PROTOTIPE ROBOT SEBAGAI PENGGERAK UJUNG PERALATAN PLASMA MEDICINE UNTUK PERAWATAN LUKA
}

\author{
Hanan Adi Wirawan, \\ Jurusan Teknik Elektro, \\ Universitas Muhamammdiyah Surakarta (UMS) \\ Surakarta,Indonesia \\ hananadhi@gmail.com
}

\begin{abstract}
Plasma medicine adalah kajian baru yang bersifat multidisiplin yang berupaya menerapkan teknologi plasma untuk terapi kesehatan, seperti perawatan luka dan penyembuhan kanker. Pada saat ini plasma medicine penggunaanya masih berbasis manual yang pengoperasiannya mempunyai resiko tinggi pada manusia sebagai operator mesin. Penelitian ini bertujuan untuk merancang sebuah alat yang mampu menggerakan plasma medicine secara otomoatis dengan pengendali jarak jauh untuk mengurangi resiko kecelakaan kelistrikan pada operator manusia. Alat ini menggunakan konsep pada mesin cnc, drawing machine, dan axidraw yang di gerakan dengan 2 motor stepper nema 17 dan dikendalikan oleh komputer melalui arduino uno, lalu plasma medicine ditempatkan pada ujung alat ini. Diharapkan plasma medicine dapat digerakan secara leluasa dan menghasilkan hasil yang lebih optimal.
\end{abstract}

Katakunci: Kesehatan, Perawatan luka, Plasma medicine, Arduino Uno

\section{PENDAhUluan}

Plasma adalah suatu fase zat keempat setelah zat padat,cair, dan gas. Plasma dapat terjadi apabila temperatur atau energi suatu zat gas dinaikan sampai zat gas tersebut menjadi terionisasi, yaitu terlepasnya elektron-elektron yang pada keaadaan normal mengelilingi inti [1]. Salah satu jenis plasma yang di terapkan dalam dunia kesehatan adalah plasma medicine. Penelitian tentang plasma medicine masih termasuk kajian yang baru dan saat ini secara intensif diteliti di negaranegara maju. Karena tuntutan keterlibatan pakar berbagai bidang ilmu inilah, maka kajian tentang plasma medicine ini bersifat multidisiplin ilmu [2].

Beberapa penelitian yang terkait dengan plasma medicine yang dilakukan oleh para peneliti di berbagai negara, memperlihatkan potensi yang sangat besar dalam penerapan disiplin ilmu ini dalam dunia dunia kesehatan. Beberapa penelitian dalam bidang plasma medicine, antara lain adalah pemanfaatan plasma dapat membasmi mikroorganisme pada luka kronis sekaligus penyembuhan pada kanker[3,4], dan perawatan luka pada binatang tikus yang memadukan penggunaan plasma dengan madu [5]. Sampai saat ini tahapan pengembangan plasma medicine masih dalam tataran penelitian yang berfokus pada penyempurnaan disain alat agar sempurna dan lebih aman digunakan untuk kulit manusia[6].

Salah satu alat yang dapat menghasilkan plasma untuk digunakan dalam bidang plasma medicine adalah Plasma jet. Alat ini di desain menyerupai pena yang memungkinkan dapat bergerak secara 3D saat aplikasi biomedis [7]. Plasma jettersebut, saat ini dalam pengaplikasiannya menggunakan tangan manusia sebagai penggerak alat. Pengoperasian manual tersebut berpotensi menimbulkan masalah, dikarenakan Plasma dioperasikan pada tegangan yang tinggi [8]. Hal itu menyebabkan tingginya resiko kejut listrik pada operator manusia. Tingginya resiko ini yang menyebabkan penelitian aplikasi plasma yang dilakukan salah satu peneliti Indonesia, tidak memegang peralatan, melainkan dengan menggerakkan preparat yang akan dikenai plasma. Hal ini tentunya akan menjadi masalah jika obyek biologis yang akan dikenai plasma merupakan obyek yang besar, misalnya manusia. Potensi masalah tersebut membangkitkan ide peneliti disini untuk membuat alat yang dapat menggerakan ujung mesin plasma dengan mesin.

Alat yang diusulkan pada penelitian bertujuan mengurangi resiko kecelakaan pada operator dikarenakan operator tidak langsung memegang ujung mesin plasma dengan menggunakan tangan. Operator akan mengendalikan alat dari jarak jauh dimana kontak langsung dengan ujung mesin plasma yang bertegangan tinggi adalah mesin. Pada penelitian ini, kami mengembangkan alat menggunakan konsep pada mesin CNC (Computer Numerical Control) [9] yang akan 
menggantikan fungsi tangan operator dan Arduino Uno[10] sebagai pengendalinya.

\section{A. Plasma (Wujud Zat)}

Plasma dapat didefenisikan sebagai percampuran kuasinetral dari elektron, radikal, ion positif dan negatif. Percampuran antara ion-ion yang bermuatan positif dengan elektron-elektron yang bermuatan negatif memiliki sifat-sifat yang sangat berbeda dengan gas pada umumnya dan materi pada fase ini disebut fase plasma. Maka secara garis besar plasma adalah gas terionisasi dan dikenal sebagai fase materi keempat setelah fase padat,cair dan fase gas.

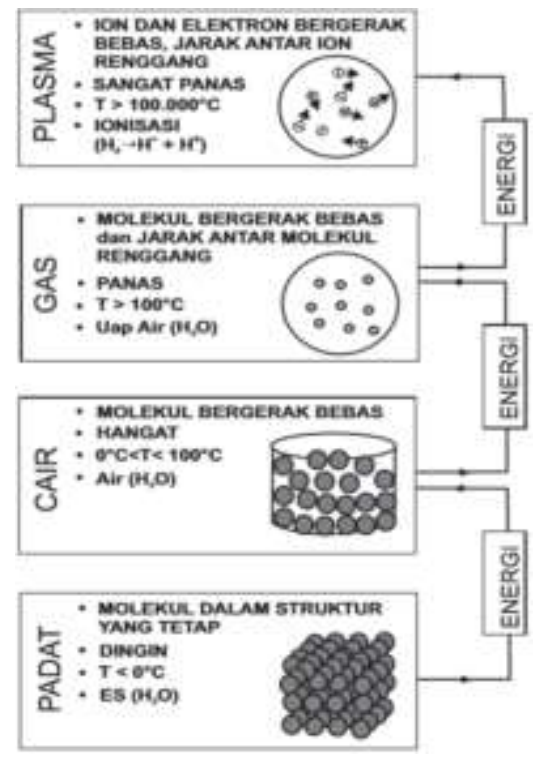

Gambar 1. Ilustrasi fase materi ke empat setelah fase padat, cair, dan fase gas

Gambar 1 Memperlihatkan proses terbentuknya plasma dari urutan padat, cair, gas dan akhirnya plasma. Ilustrsi tersebut menunjukan bahwa jika es(materi padat) mendapat energi, maka akan mencair pada suhu diatas $0^{\circ} \mathrm{C}$ menjadi air. Jika air diberikan energi sampai pada suhu $100^{\circ} \mathrm{C}$ akan menjadi uap air dengan molekul H2O. Saat molekul H2O diberikan energi secara terus-menerus, maka molekul tersebut akan terpecah menjadi $\mathrm{H} 2$ dan $\mathrm{O} 2$ dan akhirnya akan terionisasi menjadi ion-ion positif dan elektron yang pada keadaan dan ruang tertentu (microspace) terjadi keseimbangan antara ion dan elektron. Pada keadaan inilah suatu zat disebut sebagi plasma [11].

\section{B. Arduino Uno R3}

Arduino adalah pengendali mikro single-board yang bersifat open-source, diturunkan dari Wiring platform, dirancang untuk memudahkan penggunaan elektronik dalam berbagai bidang. Hardwarenya memiliki prosesor Atmel AVR dan softwarenya memiliki bahasa pemrograman sendiri. Bahasa yang dipakai dalam Arduino bukan assembler yang relatif sulit, tetapi bahasa $\mathrm{C}$ yang disederhanakan dengan bantuan pustaka-pustaka (libraries) Arduino. Arduino juga menyederhanakan proses bekerja dengan mikrokontroler, sekaligus menawarkan berbagai macam kelebihan. Jenis arduino yang digunakan di sini adalah arduino uno[12].

Untuk membuat progam pada arduino di butuhkan arduino IDE, yaitu softwareyang beroperasi pada komputer. Arduino IDE tersedia untuk berbagai macam platform, seperti Linux, Mac OS, dan Windows.Untuk mendeteksi board arduino yang telah di hubungkan pada komputer di perlukan beberapa pengaturan pada Arduino IDE. Pengaturanya adalah dengan mendeteksi jenis arduino yang di hubungkan, lalu mendeteksi sambungan port COM yang di pakai [13]. Pada Gambar 2 ini adalah Arduino UNO dan tampilan progam arduino pada komputer.

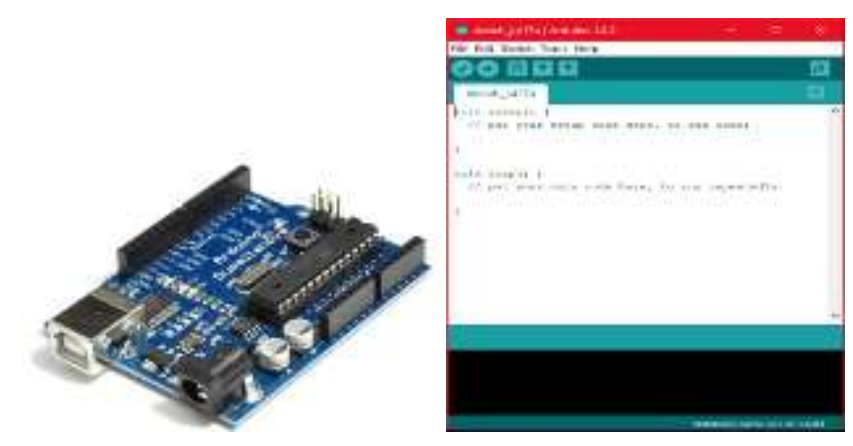

Gambar 2. Arduino unodan tampilan Arduino IDE

\section{CNC (Computer Numerical Control)}

Mesin CNC adalah sebuah sistem otomasi yang beroperasi dengan perintah yang diprogam dan disimpan di media penyimpanan. mengemukan bahwa CNC merupakan perkembangan dari NC dimana menggunakan internal micro procecor. Karena informasi yang digunakan berbentuk rumus matematik, maka dinamkan numerical cotrol. Untuk memperoleh hasil yang memuaskan semua komponen pada mesin CNC harus saling mendukung, komponen itu seperti operator (brainware), perangkat keras (hardware) dan perangkat lunak (software) [14]. Salah satu bagian utama dari mesin CNC yaitu motor stepper sebagai aktuator dan arduino sebagai pengontrolnya, bagian-bagian tersebut akan dijelaskan pada uraian dibawah ini.

Motor stepper adalah jenis motor DC yang di kendalikan menggunakan pulsa-pulsa digital, jadi gerakan mekanis yang dihasilkan merupakan hasil dari pulsa elektronis. Prinsip kerja motor stepper sebenarnya sangatlah sederhana, yakni dengan mengubah pulsa-pulsa input menjadi gerakan-gerakan mekanis yang diskrit. Oleh sebab itu agar gerakan motor stepper sesuai, diperlukan pengendali yang berfungsi membangkitkan pulsa-pulsa periodik.

Motor stepper memiliki 3 jenis yaitu tipe Variable reluctance (VR) lalu tipe permanent magnet (PM) dan tipeHybird (HB). Pada tipe Variable reluctance motor stepper inirotornya tidak memiliki magnet, rotornya adalah piringan besi dan memiliki beberapa gigi dan sebuah lilitan stator. 
Ketika lilitan stator diberi energi dengan arus DC, kutubkutubnya menjadi termagnetasi. Perputaran terjadi ketika gigigigi rotor tertarik oleh kutub-kutub stator. Gambar 3 adalah penampang melintang dari motor stepper tipe variable reluctance $(\mathrm{VR})$

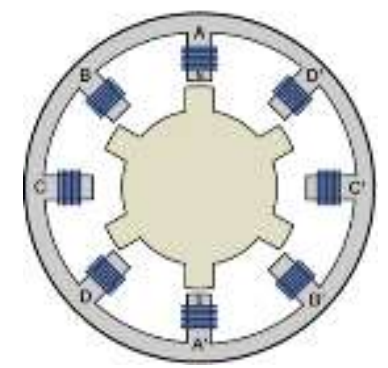

Gambar 3. Penampang Melintang Dari motor stepper tipe VR

Motor stepper yang kedua adalah motor stepper tipe permanent magnet. Stepper jenis ini memiliki rotor dengan bentuk kaleng lalu terdapat lapisan magnet dengan kutub yang berlawanan diselang-seling.

Motor ini memiliki torsi yang lebih besar karena menggunakan magnet permanen akan tetapi memiliki resolusi sudut yang buruk. Gambar 4 adalah ilustrasi sederhana dari motor stepper tipe permanent magnet.
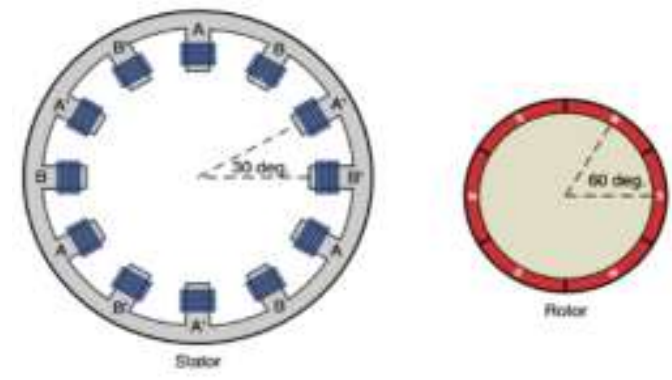

Gambar 4. Struktur internal motor stepper PM

Yang terakhir ada motor stepper tipe hybrid. Tipe motor ini adalah kombinasi dari dua motor sebelumnya yakni tipe variable reluctance dan permanent magnet. Motor stepper jenis ini memiliki gerigi seperti motor stepper VR, namun juga memiliki magnet permanen yang tersusun aksial seperti motor stepper PM. Pada Gambar 5 ditunjukan motor stepper tipe hybird.

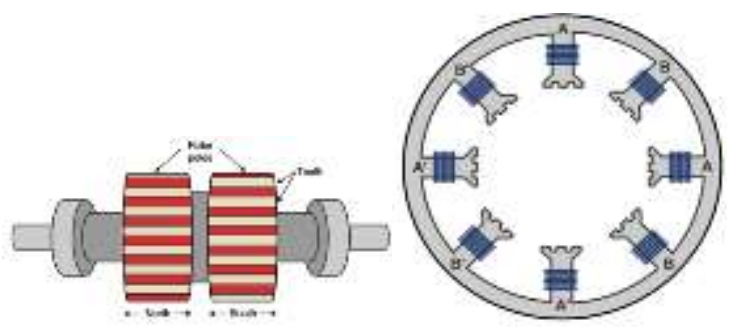

Gambar 5. Rotor dan stator stepper hybird
Selain tiga pembagian tipe motor stepper tadi, motor stepper juga bisa diklasifikasikan menjadi dua tipe lain yakni motor stepper unipolar dan motor stepper bipolar. Pembagian dua jenis motor stepper tersebut didasarkan pada metode perancangan rangkaian pengendalinya [15].

Kemudian komponen CNC selanjutnya adalah Arduino CNC Shield V3. Alat berfungsi untuk mengubah arduino menjadi pengontrol CNC. Alat ini menggunakan firmware open source dan dapat mengontrol motor stepper hingga empat motorstepper menggunakan drivermotor stepper DRV8825 atau A4988[16].

Komponen CNC terakhir adalah A4988 Stepper Motor Driver Module yang berfungsi sebagai modul penggerak yang digunakan pada motor stepper mulai dari full step, half step, 1/8 step, dan 1/6 step. Ketelitian setiap step bertambah karena dapat melakukan sampai 1/6 step, output driver ini bisa sampai $35 \mathrm{~V}$ dan 2A. Driver ini juga memiliki keamanan berupa pembatas arus berlebih dan pelindungan suhu berlebih[16]. CNC Shield V3dan Driver motor stepper A4988 ditunjukan Pada Gambar 6.

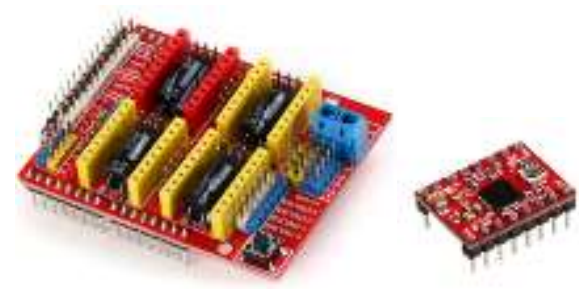

Gambar 6. Arduino CNC Shield V3 danDriver Motor Stepper A4988

\section{METODE}

\section{A. Diagram Urutan Penelitian}

Penelitian ini dilakukan dalam beberapa tahapan seperti yang terlihat pada Gambar 7. penelitian dimulai dengan menganalisa kebutuhan, yang dalam hal ini dilakukan dengan studi literatur, studi lapangan dan studi wawancara dari peneliti sebelumnya. Dari analisa kebutuhan dibuatlah desain dan perancangan alat yang dilanjutkan dengan perakitan alat dan pengujian alat, tahapan selanjutnya adalah melakukan evaluasi kinerja alat. Evaluasi dilakukan dengan menguji alat kemudian mengambil data hasil pengujian dan menganalisa datanya dengan membandingkan dengan peralatan orang lain. 


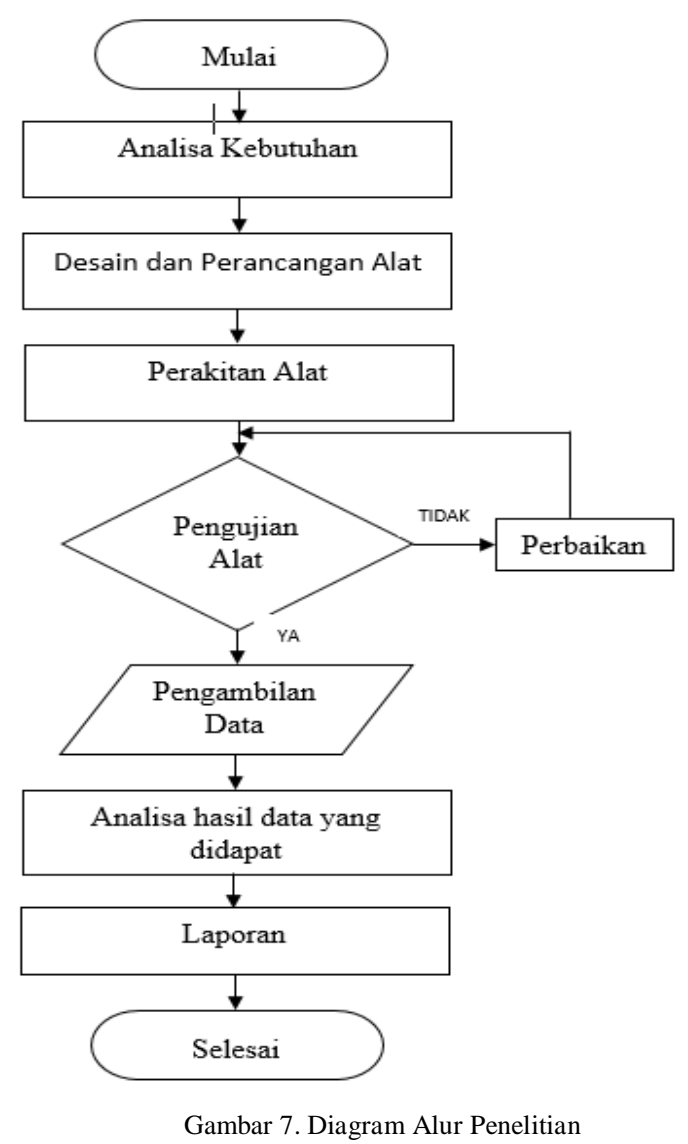

Alat dan Baahan yang Diperlukan dalam Penelitian

Pada penelitian ini bahan-bahan yang diperlukan diantaranya :

1. Plasma jet

2. 3D printing part jenis PLA+

3. Arduino uno

4. 2x Motor stepper Nema 17

5. Motor Servo

6. Smooth rod Stainless Steel $3048 \mathrm{~mm}$

7. Bearing $623 Z Z 3 \times 10 \times 4 \mathrm{~mm}$

8. GT2 2GT Belt dan Pulley Kit

9. Kabel - kabel

10. CNC Shield V3 Engraving 3D Printer

Alat-alat yang dibutuhkan diantaranya;

1. Multimeter

2. Tool Kit

3. Solder

Perancangan dan pengujian alat dilakukan di Laboratorium Teknik Elektro Universitas Muhammadiyah Surakarta.

\section{B. Perancangan Sistem}

Perancangan prototipe penggerak plasma medicine di tunjukan pada Gambar 8. Komponen utama dari mesin ini adalah Arduino Uno R3, power supply 12V, IDE Progam, CNC shield dengan drivernya, motor stepper dan servo. Perancangan perangkat lunak mesin dilakukan dengan IDE progam lalu di uploud ke arduino. Arduino digabungkan dengan CNC Shield sebagai otaknya sedangkan untuk bagian aktuatornya adalah motor stepper dan motor servo. Driver motor disini merupakan interfaceantara mesin dengan alat penggeraknya.

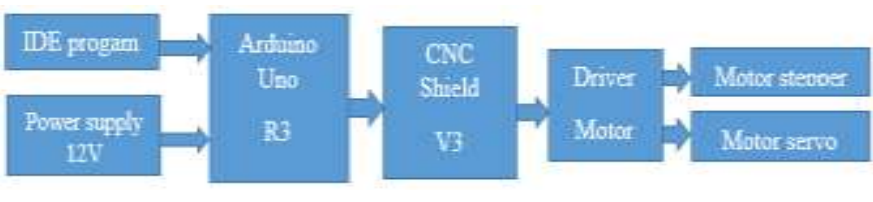

Gambar 8. Rancangan Blok diagram

\section{HASIL DAN PEMBAHASAN}

Hasil dan pembahasan terdiri dari beberapa pengujian system pada alat. Pengujian bertujuan untuk membuktikan bahwa alat yang dibuat sudah sesuai dengan rancangan yang diinginkan.

\section{A. Bentuk Alat dan Antarmuka Alat Penggerak Peralatan Plasma}

Pada penelitian ini alat penggerak plasma medicine berupa prototipe yang sebagian besar terbuat dari 3D part sebagai penopang untuk komponen-komponen seperti arduino, motor stepper, CNC shield V3 dan komponen lain. Sumber tegangan pada alat ini adalah power supply $12 \mathrm{~V}$, sedangkan untuk motor stepper di tempatkan pada sisi-sisi alat. Arduino digabungkan dengan CNC Shield yang di lengkapi dengan drivernya. Foto alat penggerak plasma medicine ditujukan pada Gambar 9.

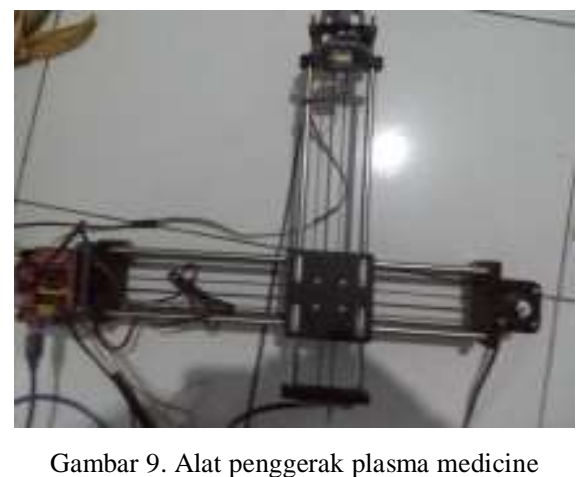

Software inscape sebagai media untuk menggambar pola yang diinginkan. Hasil gambar harus disimpan dengan format gcode file, agar gambar bisa dikirim ke arduino. Software gcode berguna untuk mentransfer hasil gambar ke arduino. Tampilan software Inscape ditujukan pada Gambar 10 dan tampilan software Gcode ditujukan pada Gambar 11. 


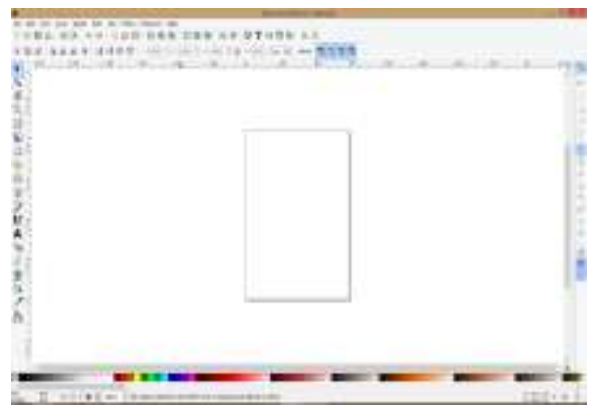

Gambar 10. Software inscape

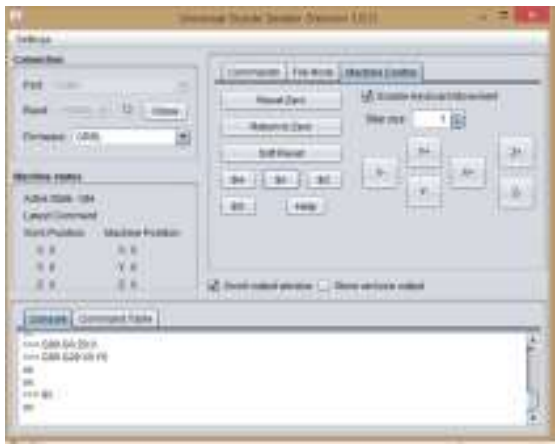

Gambar 11. Software Gcode

\section{B. Hasil Pengujian}

Pengujian dilakukan menggunkan software Inscape dengan mendesain 2 buah bentuk, yaitu zigzag dan lingkaran. Setiap bentuk memiliki memiliki 5 percobaan dengan ukuran yang berbeda-beda.

\section{Tabel 1 Hasil Pengujian MengGambar ZigZag}

\begin{tabular}{|c|c|c|c|c|c|}
\hline \multirow[b]{2}{*}{ No } & \multirow[b]{2}{*}{$\begin{array}{l}\text { Waktu } \\
\text { (detik) }\end{array}$} & \multicolumn{2}{|c|}{ Jarak Lintasan (cm) } & \multirow[b]{2}{*}{ Selisih } & \multirow[b]{2}{*}{$\begin{array}{l}\text { Persentase } \\
\text { error }(\%)\end{array}$} \\
\hline & & $\begin{array}{l}\text { Software } \\
\text { Inscape }\end{array}$ & $\begin{array}{c}\text { Hasil } \\
\text { pada } \\
\text { kertas }\end{array}$ & & \\
\hline 1 & 21 & 16 & 15.8 & 0.2 & 1.25 \\
\hline 2 & 25 & 20 & 19.9 & 0.1 & 0.5 \\
\hline 3 & 31 & 24 & 23.9 & 0.1 & 0.4 \\
\hline 4 & 35 & 28 & 28 & 0 & 0 \\
\hline 5 & 40 & 32 & 32 & 0 & 0 \\
\hline
\end{tabular}

Berdasarkan Tabel 1.1 dilakukan percobaan menggambar Zigzag sebanyak 5 kali dengan panjang lintasan yang berbedabeda. Data menunjukan rata-rata persen kesalahan dari 5 percobaan yaitu sebesar $0.43 \%$. Titik selisih tertinggi terjadi pada jarak lintasan paling kecil yaitu 16 cmsebesar 0.2
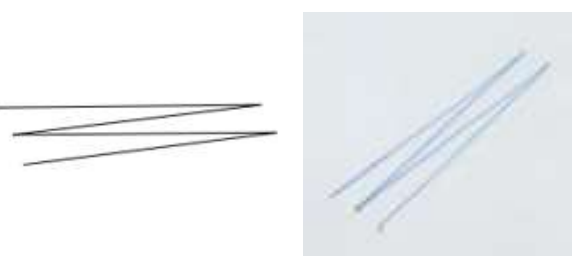

Gambar 12. Zigzag jarak lintasan $16 \mathrm{~cm}$, Software Insscape(Kiri), Hasil(Kanan).
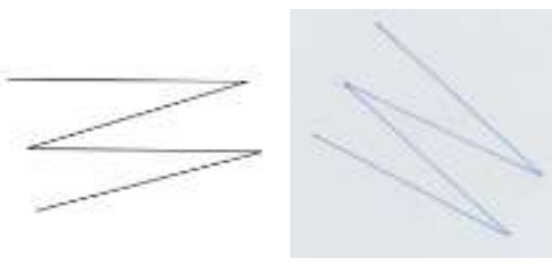

Gambar 13. Zigzag jarak lintasan 20cm,Software Insscape(Kiri), Hasil(Kanan).
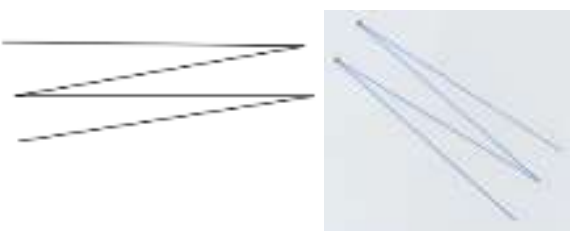

Gambar 14. Zigzag jarak lintasan 24cm, Software Insscape(Kiri), Hasil(Kanan)
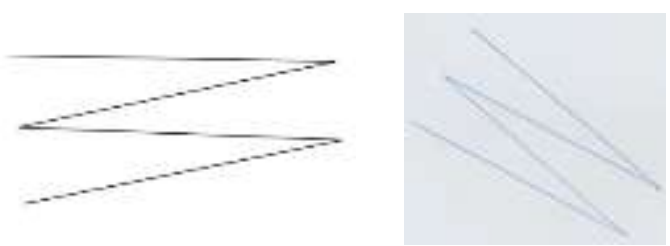

Gambar 15. Zigzag jarak lintasan 28cm,Software Insscape(Kiri), Hasil(Kanan)

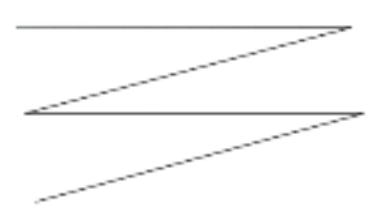

Gambar 16. Zigzag jarak lintasan 32cm,Software Insscape(Kiri), Hasil(Kanan).

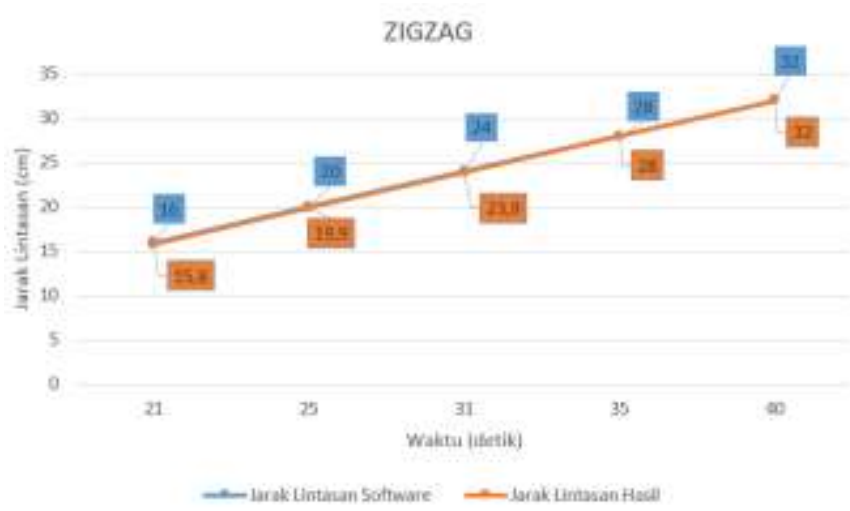

Gambar 17. Grafik perbandingan jarak lintasan gerakan zigzag antara lintasan software dan lintasan riil 
Gambar 17 merupakandiagram grafik percobaan zigzag, yang menunjukan adanya perbedaan ukuran jarak lintasan yang tidak terlalu signifikan antara desain software inscape dengan hasil realnya. Selisih yang dihasilkan tidak melebihi $0.5 \mathrm{~cm}$.

\section{Tabel 2 Hasil Pengujian MengGambar LingKaran}

\begin{tabular}{|c|c|c|c|c|c|}
\hline \multirow[b]{2}{*}{ No } & \multirow[b]{2}{*}{$\begin{array}{l}\text { Waktu } \\
\text { (detik) }\end{array}$} & \multicolumn{2}{|c|}{ Jarak Lintasan (cm) } & \multirow[b]{2}{*}{ Selisih } & \multirow[b]{2}{*}{$\begin{array}{l}\text { Presentase } \\
\text { error (\%) }\end{array}$} \\
\hline & & $\begin{array}{c}\text { Software } \\
\text { Inscape } \\
\text { (cm) }\end{array}$ & $\begin{array}{c}\text { Hasil pada } \\
\text { Kertas (cm) }\end{array}$ & & \\
\hline 1 & 14 & 6.28 & 6.3 & 0.02 & 0.32 \\
\hline 2 & 29 & 15.7 & 15.7 & 0 & 0 \\
\hline 3 & 34 & 21.98 & 22 & 0.02 & 0.09 \\
\hline 4 & 36 & 25.15 & 25 & 0.15 & 0.6 \\
\hline 5 & 40 & 31.4 & 32 & 0.4 & 1.27 \\
\hline
\end{tabular}

Berdasarkan Tabel 1.2 dilakukan percobaan menggambar Lingkaran sebanyak 5 kali dengan panjang lintasan yang berbeda-beda. Data menunjukan rata-rata persen kesalahan dari 5 percobaan yaitu sebesar $0.45 \%$. Titik selisih tertinggi terjadi pada jarak lintasan paling besar sebesar 0.4
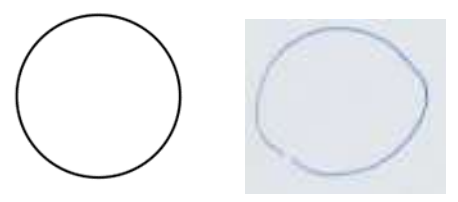

Gambar 18. Lingkaran diameter $2 \mathrm{~cm}$. Software Insscape (Kiri), Hasil (Kanan).
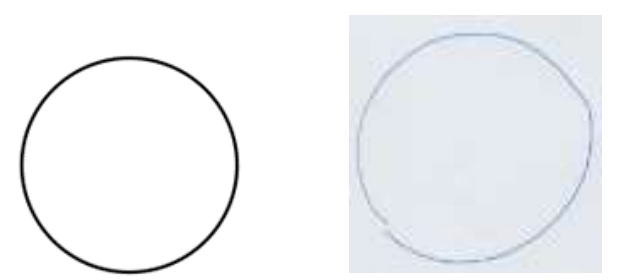

Gambar 19. Lingkaran diameter $5 \mathrm{~cm}$. Software Insscape (Kiri), Hasil (Kanan).
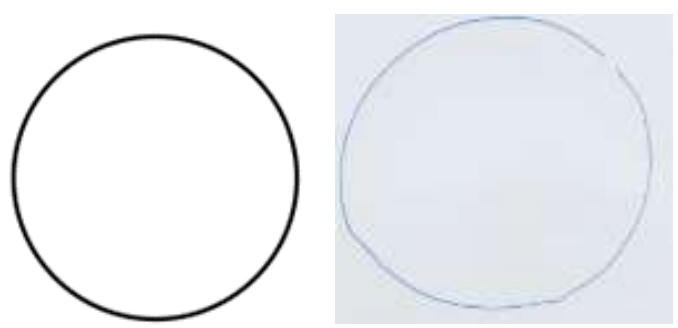

Gambar 20. Lingkaran diameter $7 \mathrm{~cm}$. Software Insscape (Kiri), Hasil (Kanan).

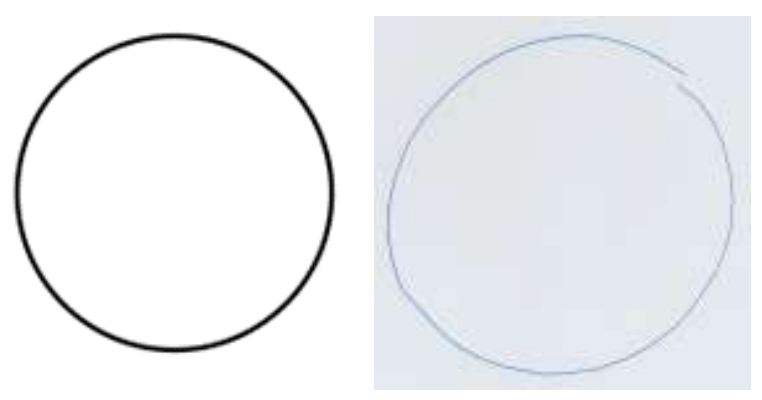

Gambar 21. Lingkaran diameter 8cm. Software Insscape (Kiri), Hasil (Kanan).
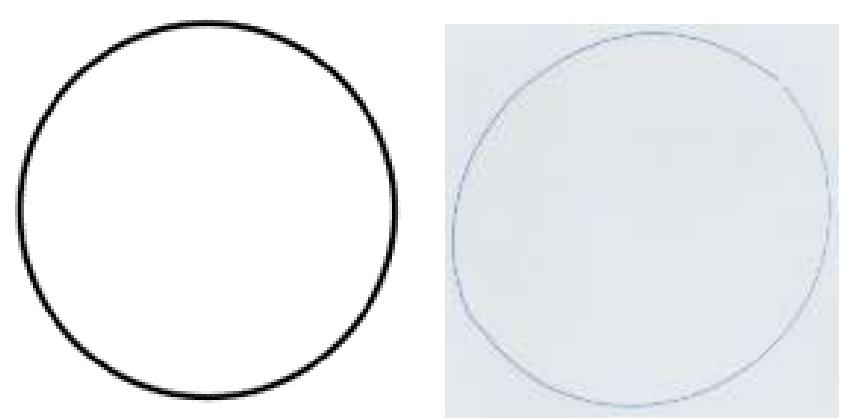

Gambar 22. Lingkaran diameter 10cm. Software Insscape (Kiri), Hasil (Kanan).

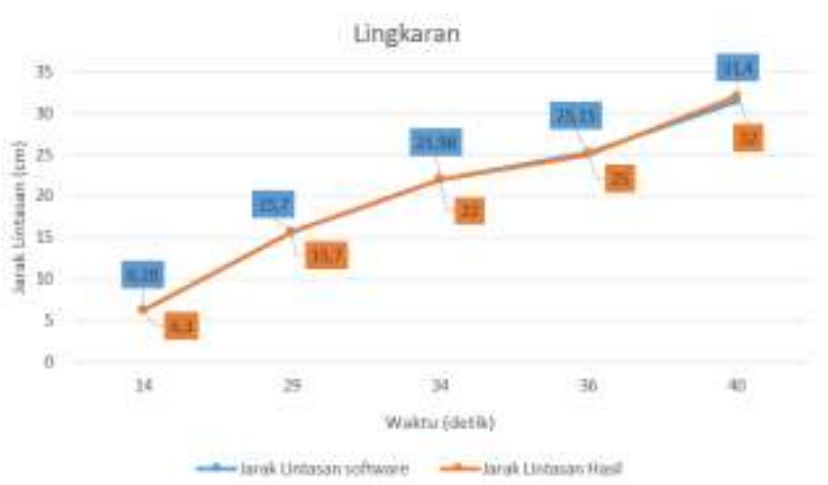

Gambar 23. Grafik Perbandingan Lintasan Lingkaran perangkat lunak dan lintasan riil

Gambar 23. menunjukan grafik percobaan lingkaran, dimana garis pada grafik terlihat linier dan perbedaan pada garis tidak begitu terlihat karena error pada setiap percobaan tidak banyak. Presentase error terbesar yaitu $1.27 \%$ yang terdapat pada lingkaran terbesar.

Hasil gambar didapat dari hasil gambar software Inscape. Pada saat percobaan alat penggerak plasma medicine berhasil menggambar lingkaran dan zigzag, namun hasil gambar tidak terlalu mirip dengan hasil gambar software Inscape, disebabkan karena penjepit pulpen tidak terlalu kencang dan 
mengakibatkan pulpen terlalu bergetar pada saat menggambar dibidang kerja.

\section{KESIMPULAN}

Berdasarkan hasil percobaan, perancangan prototipe penggerak ujung peralatan plasma medicine bekerja sesuai sistem.Bentuk lintasandi desain pada Inscape, lalu akan menghasilkan progam yang akan di proses oleh software Gcode untuk mengerakan bolpindengan menggunakan motor stepper, arduino uno dan modul CNC shield. Akan tetapi pada hasil pengujian alat, jejak lintasan tidak sama persisdengan desain pada software Inscape. Perbedaan itu terletak pada bentuk gambar dan panjang lintasannya. Hal ini terjadi karena adanya getaran dari bolpen yang belum bisa dijepit secara baik.

Penelitian ini menyisakan ruang untuk perbaikan, ada kemungkinan pengembangan lebih lanjut untuk masa depan. Diperlukan desain dan mekanik supaya mengurangi getaran pada bolpen dan menjadikan jejak lintasan lebih baik serta merapikan pengkabelan agar alat menjadi lebih rapi

\section{Daftar Pustaka}

[1] Nur, Muhammad. 2011. Fisika Plasma dan Aplikasinya. Semarang: Badan Penerbit Universitas Diponegoro Semarang.

[2] Purwata, Heri. 2015. Plasma Medicine untuk Penyembuhan Kanker. Jakarta:Republika. (Kamis 30 April 2015).

[3] Schlegel, J. Kortizer, J. and Boxhammer, V. 2013. Plasma in cancer treatment. Clinical Plasma Medicine 1(2):2-7.
[4] Salehi et al. Investigating effects of atmospheric-pressure plasma on the process of wound healing. Biointerphases. 10(2):1-7.R. Nicole, "Title of paper with only first word capitalized," J. Name Stand. Abbrev., in press.

[5] Nasruddin. et al. 2017. Evaluation the effectiveness of combinative treatment of cold plasma jet, Indonesian honey, and micro well dressing to accelerate wound healing. Clinical Plasma Medicine. 5(6):14-25.

[6] J, Lademann et al. 2013. Risk assessment of the application of tissue tolerable plasma on human skin. Clinical Plasma Medicine. 1(1):5-10.

[7] Bekeschus, S. Schmidt, A. Weltmann, K, D. Woedtke.T . 2016. The plasma jet kINPen A powerful tool for wound healing. Clinical Plasma Medicine.4(1):19-28.

[8] M.G. Kong, G. Krosen, G. Morfill et al. "Plasma medicine: an introductory review" vol. 11, 2009.

[9] Daniel. P, H and Kelly. J, F. 2009, Build Your Own CNC Machine. Apress: United State of America.

[10] Adriansyah, A. dan Hidayatama, O. 2013. Rancang Bangun Prototipe Elevator Menggunakan Microcontroller Arduino Atmega 328P. Jurnal Teknologi Elektro Universitas Mercu. 4(3):100-112.

[11] Piel, A. 2010. Plasma Physics An Introduction to Laboratory, Space, and Fusion Plasmas. Springer: Germany.

[12] Santoso, H. 2015. Panduan Praktis Arduino untuk Pemula. Elangsakti: Trenggalek.

[13] Syahriza, Firsa.T dan Ibrahim, M. 2015. Rancang Bangun Mesin CNC 4 Axis Berbasis PC. Jurnal Teknik Mesin Unsyiah. 3(2):75-79.

[14] Scarpino. M. 2015. Motors for Makers A Guide to Steppers, Servos, and Other Electrical Machines . Que Publishing: Indianapolis USA.

[15] Osoyoo. 2017. Arduino UNO + Arduino CNC Shield V3.0+A4988 Installation Guide (Diakses pada http://osoyoo.com/2017/04/07/arduinouno-cnc-shield-v3-0-a4988/, dilihat 7 September 2018).

[16] Pololu Robotic \& Electronic. 2010. A4988 Stepper Motor Driver Carrier (Diakses pada https://www.pololu.com/product/1182, dilihat 7 September 2018). 